\title{
Chantal Mouffe's Agonistic Project: Passions and Participation
}

\section{Matthew Jones: m.r.jones@gre.ac.uk}

This is an Author's Accepted Manuscript of an article published in Parallax April $9^{\text {th }} 2014$ available online: http://www.tandfonline.com/doi/abs/10.1080/13534645.2014.896546

Full Citation: M Jones, "Chantal Mouffe's Agonistic Project: Passions and Participation" Parallax 20, no. 2 (2014), 14-30.

http://dx.doi.org/10.1080/13534645.2014.896546

Note: if you do not have access to Parallax and wish to view this article, contact me via email and I will forward to you a link allowing full access.

It is Chantal Mouffe's contention that the central weakness of consensus-driven forms of liberalism, such as John Rawls' political liberalism and Jürgen Habermas' deliberative democracy, is that they refuse to acknowledge conflict and pluralism, especially at the level of the ontological. Their defence for doing so is that conflict and pluralism are the result of attempts to incorporate unreasonable and irrational claims into the public political sphere. In this context, unreasonable and irrational claims are those that cannot be translated into universalizable terms. However, for Mouffe, it is this intentional exclusionary act itself that is detrimental to a well-functioning democratic polity. It is only through the inclusion of a diverse body of subject positions that a democratic polity can be said to be truly representative of the polity, and therefore constitute a functioning and inclusive democracy.

This paper will examine Mouffe's account of agonistic pluralism. In doing so, it will demonstrate that instead of being a source of instability within the democratic discourse and therefore relegated into the private non-political sphere, passions and values that are constitutive of these subject positions ought to be incorporated into the public political sphere. Mouffe's rationale for doing so is that it is precisely through their incorporation that citizens will retain their allegiance to the democratic polity. However, as part of this examination, this paper will also draw attention to an under-developed aspect of Mouffe's account of agonistic democracy, specifically problems regarding both participation and exclusion. Whilst Mouffe does provide a robust counterpoint to both Rawls' political liberalism and Habermas' deliberative democracy, it is my contention that she fails to explain adequately what it is that persuades participants to act democratically and adhere to the requirements of agonal respect, nor what should happen when the ethico-political principles of liberty and equality are not accepted.

\section{Pluralism within Agonistic Politics}

Conflicts (or antagonisms, which is the term that Mouffe favours) occur at the point of contact between the boundaries of discourse, and emerge through acts of closure or when constituting any totality. In this context, concepts such as 'meaning', 'discourse', 
'objectivity' and 'society', are representative of such totalities. ${ }^{i}$ As these limits are an integral part of politics, politics is therefore constituted by conflict and contestation. This is in direct contrast to the thought of liberal theorists such as Rawls and Habermas, who suggest that consensus is always possible in the public political sphere. According to them, if an impasse occurs, it is not because the model itself is broken, but rather because those involved are not couching their discourse in reasonable and universalizable terms. However, for Mouffe, antagonisms are an inescapable part of the political process and discourse, as the creation of an identity, either individual or collective, is always an act of power. This power-laden formative process always requires an I/you or us/them distinction, and is therefore constantly creating an adversarial relationship to 'the other'. ${ }^{\text {ii }}$

Pluralism, as Mouffe understands it, refers to the fact that society is not a closed sphere - it is both open and porous. Accordingly, this gives rise to the creation of multiple social identities. As Laclau demonstrates, these identities are never permanent or essential, but rather, are contingent and changing. ${ }^{\text {iii }}$ It is at this point that we can begin to sketch how Mouffe's understanding of pluralism is very different from that of Rawls. Rawls views 'the fact of pluralism' as one of the defining features of the modern liberal democratic polity. By this, Rawls refers to the fact that there exists a 'diversity of reasonable comprehensive, religious, philosophical, and moral doctrines', and that this 'is a permanent feature of the public culture of democracy'. ${ }^{\text {iv }}$ Rawls makes no comment as to the desirability of reasonable pluralism; he merely confirms its existence. As such, pluralism is simply a consequence of the free exercise of reason. But for Mouffe, pluralism is not just a mere 'fact' or 'ramification'; it is fundamental to the ordering of social relations. An agonistic understanding of the social, and therefore of politics, views pluralism as a value in itself. For Mouffe, pluralism is the 'defining feature of modern democracy':

Envisaged from an anti-essentialist theoretical perspective, on the contrary, pluralism is not merely a fact, something that we must bear grudgingly or try to reduce, but an axiological principle. It is taken to be constitutive at the conceptual level of the very nature of modern democracy and considered as something that we should embrace and enhance. This is why the type of pluralism that I am advocating gives a positive status to differences and questions the objective of unanimity and homogeneity, which is always revealed as fictitious and based on acts of exclusion. ${ }^{\mathrm{v}}$

The challenge for contemporary democratic politics, therefore, is to conceptualize a democratic regime that allows for this expression of social plurality and difference, and this is a challenge that, Mouffe posits, can be met by her account of radical and plural democracy. As Mouffe argues, 'Radical democracy demands that we acknowledge difference - the radical, the multiple, the heterogeneous - in effect, everything that has been excluded by the concept of Man in the abstract.' ${ }^{\text {vi }}$ In effect, what Mouffe is advocating here is a form of radical democratic discourse which consciously incorporates many of those voices that Kantian liberalism and liberal rationalism exclude.

\section{The Agonistic Distinction between 'the Political' and 'Politics'}

It is this ontological and therefore inescapable understanding of pluralism and antagonism that leads Mouffe to make an important separation and clarification between what she refers to as 'the political' and 'politics'. There exists considerable disagreement amongst political 
philosophers about what constitutes 'the political'. In the analysis of Andrew Schaap, these views can be understood as a choice between Hannah Arendt and Carl Schmitt. ${ }^{\text {vii }}$ For Arendt, 'the political' is a space of freedom and deliberation; it refers 'to the potential experience of solidarity in moments of collective action'. viii In this category, Schaap would include thinkers such as Michael Walzer, James Tully and Claude Lefort. For Schmitt, 'the political' is a space of power, conflict and antagonism, where the potential exists for the "emergence of the friend-enemy relation'. ${ }^{\text {ix }}$ Here Schaap includes Jacques Derrida and Giorgio Agamben. However, following Fossen, I would also include Nietzsche in this list. ${ }^{x}$ Mouffe's understanding of the political is clearly located in this second perspective. As she writes:

More precisely this is how I distinguish between 'the political' and 'politics': 'the political' refers to the dimensions of antagonism which can take many forms and can emerge in diverse social relations, a dimension that can never be eradicated; 'politics' [however] refers to the ensemble of practices, discourses and institutions which seek to establish a certain order and to organize human coexistence in conditions which are always potentially conflicting because they are affected by the dimensions of 'the political'. ${ }^{\mathrm{x}}$

The denial of 'the political' in its antagonistic dimension is, in Mouffe's analysis, liberalism's 'central deficiency'. ${ }^{\text {ii }}$ With the notable exceptions of Isaiah Berlin, Joseph Raz, John Gray and Michael Walzer, it is Mouffe's contention that liberal political philosophers have continually failed to understand the ontologically plural nature of the social world. Furthermore, they do not acknowledge that this pluralism entails antagonism and conflict, and that there is no rational solution for this ontological problem (as they would envisage it). It is due to this continued belief in the harmony and neat dovetailing of values, as seen in both Rawls and Habermas, that liberalism must negate 'the political' as Mouffe understands it. Stated more directly, liberalism must shun antagonism and conflict.

The result of liberalism's denial of the antagonistic dimension of 'the political' is that, when confronted with such conflict, it is unable to take effective action. Instead of acknowledging and embracing antagonism as an ontological reality, liberalism, especially Kantian liberalism, attempts to deny it. As Mouffe posits:

Such negation only leads to impotence, an impotence which characterizes liberal thought when confronted with the emergence of antagonisms and forms of violence that, according to its theory, belong to a bygone [pre-Enlightenment] age when reason had not yet managed to control the supposedly archaic passions. ${ }^{\text {xiii }}$

It is Mouffe's contention that the main weakness of what she refers to as 'liberal rationalism' is that it is reliant upon an understanding of the social that is, in turn, premised upon an essentialist conception of identities as not being relational or constructed, but rather as being inherent to themselves ${ }^{\text {xiv }}$ It is due to this flawed understanding that liberal rationalism

[c]annot apprehend the process of construction of political identities. It cannot recognize that there can only be an identity when it is constructed as difference and that any social objectivity is constructed through acts of power. What it refuses to admit is that any form of social objectivity is ultimately political and that it must bear the traces of the acts of exclusion which governs its construction. ${ }^{\mathrm{xv}}$ 
It is at this point that Mouffe calls upon the work of Schmitt to further solidify this line of critique against liberalism, and liberal rationalism in particular. In The Concept of the Political, Schmitt argues that such an antagonistic understanding of the political could not possibly emerge out of the pure principle of liberalism. ${ }^{\mathrm{xi}}$ As liberalism is characterized by methodological individualism, it is incapable of understanding the collective, or, indeed, even the contingent, nature of identities. For liberalism, and especially for Kantian liberalism, identities are always singular and essential, fixed and non-contingent. For Schmitt, however, what makes the political unique is that it necessitates the friend/enemy distinction and discrimination. For Schmitt, 'the enemy' is defined as:

the other, the stranger; and it is sufficient for his nature that he is, in a specifically intense way, existentially something different and alien, so that in the extreme case, conflicts with him are possible. These [conflicts] can neither be decided by a previously general norm nor by the judgement of a disinterested and therefore neutral third party. ${ }^{\text {xii }}$

For Schmitt, the political is concerned with the formation of a 'we' and not of the 'they', and is therefore focused on the construction of collective identities. However, as these collective identities are formed through conflict and antagonism, they are the result not of free discussion, but of decision and exclusion. ${ }^{\text {xviii }}$ In this context, as Smith notes, 'A group of people only become a unified and coherent subject to the extent that they share a common enemy. ${ }^{\text {xix }}$ Schmitt's understanding of the political, therefore, highlights the inescapability of conflict and antagonisms. In Schmitt's analysis, liberalism negates the political in its antagonistic aspect as it tends to represent pluralist conflicts in terms of intellectual differences of opinion or economic competitors. As Schmitt notes:

In a very systematic fashion liberal thought evades or ignores state and politics and moves instead in a typical recurring polarity of two heterogeneous spheres, namely ethics and economics, intellect and trade, education and property. The critical distrust of state and politics is easily explained by the principle of a system whereby the individual must remain terminus a quo [the starting point] and terminus ad quem [the end point]. ${ }^{\mathrm{xx}}$

Schmitt does not deny that within the context of the friend/enemy dichotomy consensus can emerge. This consensus can only be achieved, however, through the exercise of power and exclusion, as opposed to the power-free rational discourse that is espoused by theorists such as Rawls or Habermas. ${ }^{\text {xxi }}$ This interpretation of the political and exclusionary nature of how consensus is achieved is important as it undermines much of the recent work of Rawls and Habermas. As Mouffe writes:

Consensus in a liberal-democratic society is - and always will be - the expression of a hegemony and the crystallization of power relations. The frontier that it establishes between what is and what is not legitimate is a political one, and for that reason it should remain contestable. To deny the existence of such a moment of closure, or to present the frontier as dictated by rationality or morality, is to naturalize what should be perceived as a contingent and temporary hegemonic articulation of 'the people' through a particular regime of inclusion-exclusion. ${ }^{\text {xii }}$

This point has important political implications that I shall examine in more detail later in this paper. Briefly, both Laclau and Mouffe argue that the liberal democratic discourse reduces all 
political debate to issues about proceduralism and administration. ${ }^{\text {xxiii }}$ This is done through the construction of a political consensus that actively excludes Schmitt's conception of the 'enemy'. However, radical democracy consists of acknowledging the exclusionary nature of the political, and therefore attempts to incorporate into the political fold as many voices as possible. As Smith notes, 'For radical democratic pluralism...the political consists in the struggles to hegemonize the social; that is, in the struggles to reconstruct the social and its subjects through the institutionalization of democratic and egalitarian worldviews. 'xxiv Radical democracy, therefore, is concerned with both acknowledging the friend/enemy and we/they distinction, and trying to expand the contingent frontiers of this separation in order to incorporate part of the enemy into the friend.

\section{Emancipatory Agonism}

What then, are the normative implications of the points raised thus far for the agonistic critique of liberal democracy? In order to accurately address this question, it is important that we make a distinction between two fundamentally different forms of agonism, that is between perfectionist and emancipatory agonism. In order to develop this separation, I will draw upon the recent scholarship of Fossen. ${ }^{\mathrm{xx}}$ The distinction has received scant attention within the academic literature. Indeed, the diversity of thought within the emancipatory agonistic project itself has attracted substantially more attention, and thus produced more literature, than this larger dichotomy within the agonistic project broadly conceived.

Whilst there exists a degree of common ground between these two interpretations of agonism, especially at the level of analysis, they differ dramatically in their utilization of the agonistic critique. Perfectionist agonism is aimed at the cultivation of nobility, whereas emancipatory agonism is used to challenge consensus and social/political exclusion. Of the two interpretations, emancipatory agonism is best suited to meet the demands of Mouffe's agonistic project, and will therefore be the focus of discussion. ${ }^{x x v i}$ As its name suggests, emancipatory agonism is driven by the concept of emancipation. However, this is a very different understanding of emancipation from that of traditional accounts of liberalism. Whilst liberalism is often associated with the establishment and preservation of (negative) liberty among individuals, emancipatory agonism is concerned with exposing and remedying the harms and injustices that are caused by violence and exclusion, which are themselves the result of liberalism's attempts to deny or restrict pluralism. As opposed to the liberal discourses of Rawls or Habermas, emancipatory agonism is not concerned with transcending relations of power, or attempting to bring individuals and groups together at some uncontested point of measure. 'Rather', as Fossen argues:

The term emancipation is meant as an umbrella that captures attempts to redress instances of what agonists variously identify as inequality, injustice, exclusion, marginalization, subordination, and violence, while acknowledging that these harms are to some extent inherent in politics. The emancipatory value of contestation lies in its capacity to allow individuals to challenge these harms and thereby possibly diminish them. In other words, agonists seek to empower citizens to challenge the harm endemic to their politics. ${ }^{\mathrm{xxvii}}$

In order to meet the aims of emancipatory agonism, what is needed is a democratic model that is capable of achieving what the liberal rationalist's democratic model cannot - it must 
be able to grasp the true and unavoidable nature of Mouffe's conception of 'the political'. Accordingly, Mouffe wishes to propose a democratic model that places the questions of power, antagonism and exclusion 'at its very centre'. xxviii Laclau and Mouffe have already examined the theoretical foundations of this approach in Hegemony and Socialist Strategy. ${ }^{\text {xix }}$ Here they concluded that the goals of socialism can only be achieved through democratic means because the strict and rigid class-based economic analysis of Marx was no longer tenable. ${ }^{\mathrm{xxx}}$ The crux of this text (as it relates to the focus of this paper) is that it is only through acts of power that social objectivity is constituted. The implications of their thesis are quite profound: it follows that social objectivity is therefore political, and will always possess traces of that which it excludes as part of its constitution. ${ }^{\text {xxi }}$ Objectivity is never pure as it always contains trace elements of the excluded 'other'.

In this context, for Laclau and Mouffe, hegemony refers to the meeting point where objectivity and power converge (or alternatively, at the point of mutual collapse). This suggests a very different way of understanding power. Under the liberal rationalist and democratic consensus view, power was always viewed as existing externally to the relationship that took place between two pre-constituted identities. But under this new understanding, power is viewed as constituting the identities themselves. ${ }^{\text {xxxii }}$

This in turn gives rise to a new way of viewing political orders and practices. They can no longer be viewed simply as representing the interests and desires of pre-constituted identities. Instead, because any political order is essentially the expression of a hegemonic articulation (the point where objectivity and power converge/collapse), political orders and practices are nothing more than a particular and contingent ordering of power relations. ${ }^{\text {xxiii }}$ Put another way, if all political orders are the expression of a particular hegemonic articulation, this would suggest that all political orders are simply contingent expressions of the meeting point between objectivity and power.

This reworking of the nature of political orders and practices results in a transformation of the relationship between democracy and power. Under a traditional liberal democratic understanding of this relationship, power plays a decreasing role in constituting social identities as the level of democracy spreads. This is an inverse relationship: as democracy increases, power should decrease. The ultimate aim of this traditional relationship is the domination of democracy over power. ${ }^{\text {xxiv }}$ But as Mouffe has argued, following the analysis that she and Laclau set out in Hegemony and the Socialist Strategy, power relations are constitutive of the social. Therefore, the central focus of democracy and the democratic discourse ought to shift in order to reflect this change adequately. We need to reconceptualise what democratic politics ought to be about. Instead of being concerned with the elimination of power relations, democratic politics ought to be concerned with 'how to constitute forms of power [that are] more compatible with democratic values'. ${ }^{\mathrm{xxv}}$ This, then, becomes the central aim of both radical and plural democracy:

To acknowledge the existence of relations of power and the need to transform them, while renouncing the illusion that we could free ourselves completely from power, this is what is specific to the project of 'radical and plural democracy' that we are advocating. ${ }^{\text {xxxvi }}$

Perhaps the most profound implication of this radical reconceptualization of the democratic project is that it rules out the idea of a normative democratic consensus and harmonization of 
values, a concept that is fundamental to both the Rawlsian and Habermasian political project. Given this new understanding of the relationship between power and identity, it is no longer possible for a delineated social actor to claim they represent the totality, and thus have control over its theoretical foundations. ${ }^{\mathrm{xxxvii}}$

This then provides Mouffe with the theoretical terrain that she needs to formulate her conception of agonistic pluralism. For Mouffe, agonistic pluralism is more closely aligned with Richard Rorty's idea of 'redescribing' the basic premise of liberal democracy 'metaphorically'. Thus, not only is there an acknowledgement of liberal democracy's conflictual and agonistic character, but there is an accompanying acknowledgement of its importance. It is only once this understanding of the nature of 'the political' is embraced that one can begin to move towards the challenge that liberal democracy faces, which is the attempt to mitigate the antagonisms that exist within 'politics' ${ }^{x x x v i i i}$ As Mouffe writes:

Indeed, the fundamental question is not how to arrive at a consensus reached without exclusion, because this would require the construction of an 'us' that would not have a corresponding 'them'. Yet this is impossible because...the very condition for the constitution of an 'us' is the demarcation of a 'them'. The crucial issue then is how to establish this us/them distinction which is constitutive of politics in a way that is compatible with the recognition of pluralism. ${ }^{\text {xxix }}$

Thus, the political issue becomes one of establishing an us/them distinction in such a way that it remains compatible with pluralist democracy. In order to achieve this desired outcome, we must reformulate our understanding of 'them'. Instead of interpreting 'them' as an enemy that needs to be eradicated, we ought to view 'them' as an adversary, as someone whose ideas we will fight against, but whose right to defend those ideas are never questioned.

\section{The Inclusive Nature of Agonistic Pluralism}

Although this may appear at first glance to be just an issue of semantics, this is not the case, as the distinction between an adversary and an enemy is an important one. Whilst this shift does not remove the points of conflict that may arise with the us/them distinction, it does relocate the conflict onto common ground. Thus, whilst an adversary is still an enemy, they are now perceived as a legitimate enemy; that is to say they are an enemy that, despite what other differences may exist, shares the belief in the legitimacy of what Mouffe refers to as 'the ethico-political principles of liberal democracy: liberty and equality'. ${ }^{\mathrm{xl}}$ Whilst those within this us/them distinction may disagree on the exact meaning, parameters or implementation of these two ethico-political principles, they continue to accept their importance. Contrary to the thought of liberal rationalists such as Rawls and Habermas, this is not a disagreement that can be mediated through rational or neutral discussion or deliberation. It is owing to this impossibility that politics retains its antagonistic character. Whilst the adversaries within the us/them distinction may cease to disagree, or come to a temporary compromise, a specifically rational consensus is impossible. ${ }^{\text {xli }}$

To draw an analogy that dovetails neatly with Wittgenstein's understanding and use of games, whilst two chess players may possess radically different philosophies on how to play chess (traditional, modern or hyper-modern openings, for instance), they agree on the existing pre-set rules of the game. Despite their differing philosophies, they both accept how certain pieces can and cannot be moved, and how the game itself is won or lost. Certain openings or 
styles of play may be accepted as being better than others only under specific conditions. As such, therefore, both players accept the pre-set rules of the game. Indeed, participation itself is predicated upon acceptance of these rules.

This shift from enemy to adversary also requires a corresponding shift from antagonism to agonism. Political relations should no longer be understood as antagonism between enemies, but rather as agonism between adversaries. ${ }^{x l i i}$ Whereas antagonism refers to the struggle between enemies who wish to eradicate each other, agonism refers to a struggle between adversaries who accept the pre-set rules of the game. Therefore, the aim of emancipatory agonistic politics, and of democratic pluralism itself, is to transform antagonistic relationships into agonistic relationships.

It is at this point, however, that Mouffe could be open to a charge of hypocrisy or contradiction. How is it that Mouffe believes that a rational consensus is impossible, yet argues that the same parties are able to pledge allegiance to the ethico-political principles of liberal democracy, namely liberty and equality? In other words, why are the participants in any dialogue unable to reach a rational consensus, yet appear to be able to agree on the preset rules of the game itself? More specifically, how is this agreement on the ethico-political principles of liberal democracy different from the forms of consensus that drive the work of Rawls and Habermas? In order to address this concern, Mouffe differentiates between two forms of consensus, the (impossible) rational consensus that is required by liberal rationalists, and a much thinner 'conflictual consensus' that is required for the success of democratic pluralism.

As its name suggests, this thin conflictual consensus operates at a much lower level of agreement than its more substantial relative. A conflictual consensus refers only to an agreement on the pre-set rules of the game; that is, an allegiance to both liberty and equality. ${ }^{\text {xliii }}$ It does not refer to its specific form nor how it is to be implemented.

Accordingly, this thin conflictual consensus can be expressed in many different ways, such as liberal-conservative, social-democratic, neo-liberal or radical-democratic forms of political association. Whilst they all share an allegiance to the ethico-political principles of liberty and equality, what differentiates them is their unique interpretation of the common good, and thus their attempts to implement a very specific version of hegemony. These different expressions of the ethico-political principles provide citizens with the platforms from which their democratic objectives can be built, and from which an enemy can be transformed into an adversary. It is only from these different interpretations that antagonism can be transformed into agonism. ${ }^{\text {xliv }}$

It is at this stage that we can see the emergence of another important point of differentiation between liberal rationalism and Mouffe's agonistic pluralism. For Mouffe, one of the strengths of an agonistic approach to politics is that it does not require that passions or beliefs that are deemed to be unreasonable or irrational be removed from the political process in order to achieve the elusive rational consensus. Models that rely upon a form of rational consensus, such as those espoused by Rawls and Habermas, intentionally try to remove these passions and beliefs from the political process. As Walsh notes, traditional forms of deliberation tend to marginalize personal experiences and emotional expressions from the political process. ${ }^{\text {xlv }}$ 
The reason for this relegation is due to the apparently mutually exclusive nature of legitimate universalizable concerns and what are considered to be the expressions of nonuniversalizable particularist or contingent passions. The most cogent expression of this can be located in Rawls' concept of 'the priority of the right over the good', with its strong Kantian underpinnings. If these contingent and particularist elements are introduced and incorporated into the public political sphere and the political process, it is feared that they may undermine or jeopardize stability and advances towards the creation of a rational consensus. Such passions and values can find expression in forms such as religion, gender, sexuality and ethnicity.

But for Mouffe, it is a mistake to attempt to relegate or minimize the relevance and importance of such non-universalizable passions and beliefs. Contrary to what Rawls or Habermas may argue, a consensus built around the ethico-political principles of liberal democracy - even if it is only a temporary consensus - is more likely to be achieved 'by multiplying the institutions, the discourse, [and] the forms of life that foster identification with [such] democratic values'. ${ }^{\text {xlvi }}$ Thus, passions and beliefs are central to an agonistic understanding of politics. Accordingly, 'the prime task of democratic politics', Mouffe asserts, 'is not to eliminate passions or to relegate them to the private sphere in order to establish a rational consensus in the public sphere. It is, rather, to attempt to mobilize those passions towards democratic designs. ${ }^{\text {xlvii }}$

In Mouffe's analysis, this conscious relegation of the importance of passions and beliefs, an act of which both Kantian liberalism and liberal rationalism are guilty, has two important and opposing political and social implications. First, it tends to produce 'extreme forms of individualism' that have become so widespread they 'threaten the very social fabric'. ${ }^{\text {xlviii }}$ Recent examples of this extreme individualism can be found at both ends of the socioeconomic spectrum. The actions of some of those associated with the finance sector, which led to the recent global financial crisis - individuals who were once referred to as the 'masters of the universe', as well as of those involved in the 'bonus culture' within the city are as much an expression of extreme individualism as the actions of some of the looters in the London riots of 2011.

Second, individuals and groups tend to search for forms of collective identification that exist outside the traditional forms of political association and participation. The reason for this is that the non-universalizable contingent or particularist characteristics that are often understood by some people to be constitutive of their very identity are not allowed to be associated with conceptions of citizenship. Whilst this search for collective identification is not a negative desire or outcome in and of itself, it often results in forms of collective identification 'that put into jeopardy the civic bond that should unite a democratic political association'. ${ }^{\text {xlix }}$ This is often reflected in the growth of various political, religious, moral and ethnic fundamentalisms. As Mouffe writes:

Democracy is in peril not only when there is insufficient consensus and allegiance to the values it embodies, but also when its agonistic dynamic is hindered by an apparent excess of consensus, which usually masks a disquieting apathy. It is also endangered by the growing marginalization of entire groups whose status as an 'underclass' practically puts them outside the political community. 
In order to curtail these negative consequences that are the direct result of the unrealistic demand for a rational consensus and the exclusion of passions, what is required is a form of political association that draws people in and encourages participation, instead of pushing them away, hence the fundamental importance of incorporating passions and beliefs into the political fold. As already noted, this is more likely in a political system that acknowledges conflict and identity, such as agonistic pluralism. As Mouffe notes:

Mobilization requires politicization, but politicization cannot exist without the production of a conflictual representation of the world, with opposed camps with which people can identify, thereby allowing for passions to be mobilized politically within the spectrum of the democratic process. ${ }^{\text {li }}$

Thus, whilst the rationale behind the Rawlsian or Habermasian approach to removing passions and beliefs from the political discourse is that they are not considered to be conducive to achieving a consensus, Mouffe demands their inclusion precisely because they are more conducive (to the creation of such a consensus). A consensus is more likely to be achieved, therefore, through the mobilization of passions and the creation of both subject positions and power relations that are compatible with liberal democracy. As Gürsözlü concludes:

So, as opposed to the rationalistic discussion-based procedures of the deliberative account, Mouffe's (agonistic) understanding of politics proposes different techniques to foster democratic institutions and achieve such consensus by mobilizing passions around democratic values, creating forms of power that are more compatible with democratic principles, and multiplying the ensemble of practices that makes possible democratic individuals. ${ }^{\text {lii }}$

This, therefore, suggests a fundamental reformulation of our understanding of both consensus and conflict. The liberal rationalism of Rawls and Habermas is designed in such a way as to achieve a stable consensus through the intentional exclusion of passions and beliefs, and through the intentional exclusion of all that is deemed to be particularist and contingent. However, whilst Rawls and Habermas may desire a stable and rational consensus, what is actually achieved is a narrow, unstable and ultimately exclusionary consensus. As Schaap writes, when comparing the consensus of Mouffe to that of the deliberative democrats, 'The requirements that particular claims could be represented in terms of the general principles of public reason may therefore have the effect of silencing certain claims because they appear unreasonable or are simply inexpressible in these terms. "liii In contrast, the thinner conflictual consensus of Mouffe is a distinctly positive and inclusive conception of consensus. Even though this consensus is anchored firmly to the ethico-political principles of liberal democracy, because it does not ascribe any substantive content to these principles, and allows for the incorporation of the particularist and contingent into the political fold, it has the potential to be more inclusive than that of the liberal rationalists. Thus, even though both Mouffe and the liberal rationalist, such as Rawls and Habermas, want to achieve a similar goal (a stable, inclusive and functioning democratic polity), they go about it in radically different and opposing ways.

Given the diverse demographics of those who participate in the formulation of this conflictual consensus, it is inevitable that disagreement and conflicts will arise. However, contrary to what the liberal rationalists and adherents of Kantian liberalism hold, this conflict or 
confrontation should not be understood as a sign of imperfection. Rather, as Mouffe draws to our attention in the introduction to The Return of The Political, 'A healthy democratic process calls for a vibrant clash of political positions and an open conflict of interests. If such [a clash] is missing, it can too easily be replaced by a confrontation between non-negotiable moral values and essentialist identities. 'liv

\section{Agonistic Democracy: Participation and Exclusion}

Those who are grappling with Mouffe's radical democratic project should not, however, misinterpret or misconstrue what she is trying to achieve, nor its implications. This is an important point, and it needs to be considered by those who are supportive of this reinterpretation of democracy, and equally by those who are critical of it. It would be wrong to conclude that it is Mouffe's contention that her radical democratic project, underpinned by her account of agonistic pluralism, is the utopian panacea for all of those who are excluded by the rational and consensus model of liberalism. Whilst her radical democratic project is defended on the grounds that it is more capable of generating the assent of citizens within the modern liberal democratic polity than is the liberal rational or consensus model of Rawls and Habermas, there is no claim that it is able to gain the assent of all citizens. Exclusion is still a possibility in this account of democracy. Accordingly, the remainder of this paper will examine some important questions regarding the twin issues of participation and exclusion that are raised by such a radical democratic project.

The strength of Mouffe's democratic framework is the acceptance of a shift in the discourse from the 'moral' to 'the political'. What were previously viewed as constituting universal and reasonable grounds for achieving a moral (and therefore ultimately political) consensus are now seen as political constructs, achieved, in part, through acts of exclusion. As Mouffe argues, instead 'of trying to erase the traces of power and exclusion, democratic politics requires us to bring them to the fore, to make them visible so that they can enter the terrain of contestation. ${ }^{\text {lv }}$ Democratic deliberation will still require a clear distinction between what is reasonable and what is not. However, this demarcation is in perpetual contestation, and must be viewed as political, not moral. Whilst, as this paper has demonstrated, Mouffe's project is more nuanced than this, it is the political construction of both reasonableness and consensus that lies at the heart of her reformulation of the agonistic democratic framework. However, whilst I concur with Mouffe that this shift from the moral to the political is more likely to be inclusive and encourage participation from previously excluded citizens (at either the individual or collective level), there are still a number of troubling questions that need to be addressed.

First, it is not clear why the parties involved should accept the premise of an agonistic democratic framework. Depending on the degree of disagreement or difference between the parties involved (or, as Schaap has noted, the harm suffered due to past injustices in deeply divided societies such as South Africa, Chile and East Timor ${ }^{\text {lvi }}$ ), insisting that participants view each other with agonistic respect may be difficult to achieve. The shift from antagonism to agonism, from enemy to adversary, a shift that is fundamental to Mouffe's democratic framework, should not be underestimated. To situate the terms of debate in such a way requires a substantial conceptual change from all participants. Let us refer once again to the example of the two chess players. We have already established that each player may possess different views on how best to play. But even prior to this, each participant must want to play 
the game in the first place, and in doing so, accept their opponent's right to play, and that defeat is a distinct possibility.

Accordingly, the first problem that Mouffe's account of agonistic democracy must overcome is to convince the participants that not only is it in their best interest to do so, but it is also in the best interest of the polity as a whole. This requires not only a substantial change in how one views the political process itself, but also how one views the other participants. I posit that Mouffe does not provide us with a sufficiently robust explanation as to how this shift from enemy to adversary will come about. As Kapoor correctly brings to our attention:

a lot is unexplained here: where do her imperative constructions - "all the participants will recognize" and "we need" - come from? On what are they based? What will compel these groups to act democratically? What will guarantee or impel their legitimacy? In the absence of answers to these questions, it is difficult to interpret Mouffe's "logic of equivalence" as anything other than voluntarism. She appears satisfied that social movements and protest groups will by themselves discover and practice democratic citizenship, in spite of evidence... to the contrary. ${ }^{\text {lvii }}$

Here, perhaps, we can see a paradox in Mouffe's account of agonistic democracy. In societies that are beset by a substantial degree of difference and disagreement, Mouffe's agonistic democratic framework may offer a viable political solution to exclusion, instability and apathy, as well as possessing a number of distinct conceptual advantages over Rawls' political liberalism and Habermas' deliberative democracy. Yet it is precisely in these environments that it may struggle to be adopted.

However, let us assume that the participants have accepted the requirements for an agonistic account of democracy. A further problem remains regarding the lack of institutionalized procedures and frameworks, as this may result in the practitioners themselves having to develop the rules for discourse. ${ }^{\text {lviii }}$ Whilst this, in and of itself, is not problematical, it may result in negative consequences. In such negotiations it is rare for some type of power imbalance not to exist between the various participants. Even if all parties accept the ethicopolitical principles of liberty and equality, such an uneven outcome may be an unintended consequence. For example, feminists have drawn our attention to the fact that women often work a 'double-shift' of both wage labour and domestic labour. This severely undermines their ability to participate in any form of democratic discourse and framework, thus often perpetuating the gendered division of labour and political exclusion. ${ }^{\text {lix }}$

Furthermore, there is still the contested issue regarding the construction of that which is deemed to be reasonable. It has already been established that any consensus reached is political, as opposed to moral, in nature. But even when this is taken into account, such a political consensus may never be achieved if the parties involved are unwilling to cede ground on certain issues, especially if those issues are of fundamental importance to their sense of identity or belonging. For example, certain communities may agree to the ethicopolitical principles of liberty and equality, but with the proviso that certain issues are simply not open for discussion or compromise.

Certain forms of pluralism can be readily translated into these ethico-political principles, and, accordingly, can easily be incorporated into the political fold. ${ }^{1 \mathrm{x}}$ But what of those individuals or groups who do not accept these twin principles? As Deveaux correctly points out: 
agonistic democrats have so far little to say about citizens who may refuse to cooperate with other citizens, or about groups that have an entrenched interest in having a conflict continue unresolved. These are difficult cases, meriting special political measures to compel agreement, rather than more talk: consider the situation of a community that has decided to live separately from the rest of society, and the case of an ethnic group whose sole goal is that of political secession. ${ }^{\text {.xi }}$

In a 2011 lecture at the University of Kent, Mouffe suggested that such individuals and groups ought to be excluded. ${ }^{\text {lxii }}$ However, it is unclear exactly what she meant by this. Is it her position that it is the views themselves that ought to be excluded, while those who hold them retain the full rights and entitlements associated with citizenship? Or, more forcefully, is it her position that as a direct consequence of holding such views, the individuals and groups themselves lose their rights and entitlements? This is an important issue that, thus far, Mouffe has not addressed in any academic literature.

However, it need not be that all citizens support these ethico-political principles. What is necessary, though, is that the vast majority do. I draw this distinction because, as Shorten suggests, the existence of a small number of people who, for various reasons, reject the ethico-political principles of liberal democracy, does not compromise the stability of the larger democratic community or institutions. ${ }^{\text {lxiii }}$ This has been demonstrated in America with the various Amish, Mennonite and Hudderite communities, who have successfully isolated themselves from the larger social and political community. Thus, even the existence of a small percentage of the population who continually refuse to accept the ethico-political principles of liberal democracy need not undermine social stability, irrespective of whether these groups fall under the banner of thin or thick pluralism. Of course, the implication of this caveat is also true: should, for whatever reason, the numbers of these 'non-participants' rise to the point where their continued refusal to accept the legitimacy of the ethico-political principles of liberal democracy begins to undermine social stability, then, prima facie, the state may have grounds to act. To clarify, though, this action on behalf of the state should not be motivated by the existence of communities who refuse to participate, but rather, only if and when the numbers of these non-participants rises to the point where it begins to undermine social and political stability.

\section{Concluding Remarks}

Mouffe's agonistic project, premised on her ontological account of pluralism, provides a strong rebuttal to the work of liberal rationalists such as Rawls and Habermas. Through its focus on hegemony and political contestation, agonistic democracy can open new spaces for participatory politics, incorporating actors that may otherwise be excluded. However, perhaps the real strength of Mouffe's agonistic account of democracy lies not in the form of its political solution, but rather that it provides a different way of viewing and understanding political exclusion, conflict and difference.

Yet despite the strength of Mouffe collective writings on radical pluralism and agonistic democracy, questions still remains regarding issues of both participation and exclusion. Instead of viewing this as a weakness, I propose that it ought rather to be viewed as an area for future research. Agonistic pluralism and radical democracy is an ongoing project whose parameters are not yet fixed. Indeed, given the nature of this project, it is doubtful whether 
these parameters can or ought to be fixed. What this open-ended democratic project does allow, however, is a continued defence of the value of democracy, whilst simultaneously attempting to broaden the scope of the actors able to participate. Participation and inclusion within this project ought to be seen, by those actors who may be critical of the ethico-political principles of liberty and equality, as being more beneficial than non-participation and, ultimately, exclusion.

\section{Notes}

I would like to thank David Bates, John Horton and David McLellan for their feedback on an earlier version of this paper.

i Ilan Kapoor, 'Deliberative Democracy or Agonistic Pluralism? The Relevance of the Habermas-Mouffe Debate for Third World Politics', Alternatives: Global, Local and Political , 27:4 (2002), p.465.

ii Ilan Kapoor, 'Deliberative Democracy or Agonistic Pluralism?', p.465.

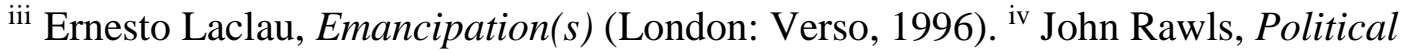
Liberalism (New York: Columbia Press), p.36. ${ }^{v}$ Chantal Mouffe, The Democratic Paradox (London: Verso, 2000), p.19. ${ }^{\text {vi }}$ Chantal Mouffe, The Return of the Political (London: Verso, 2005), p.13. ${ }^{\text {vii }}$ Andrew Schaap, 'Political Theory and the Agony of Politics', Political Studies Review, 5:1 (2007), p.60.

iv John Rawls, Political Liberalism (New York: Columbia Press), p.36.

${ }^{v}$ Chantal Mouffe, The Democratic Paradox (London: Verso, 2000), p.19.

${ }^{v i}$ Chantal Mouffe, The Return of the Political (London: Verso, 2005), p.13.

vii Andrew Schaap, 'Political Theory and the Agony of Politics', Political Studies Review, 5:1 (2007), p.60.

viii Andrew Schaap, 'Political Theory and the Agony of Politics', p.60.

ix Andrew Schaap, 'Political Theory and the Agony of Politics', p.60.

${ }^{x}$ Thomas Fossen, 'Agonistic Critiques of Liberalism: Perfectionism and Emancipation', Contemporary Political Theory, 7:4 (2008), pp.376-394.

${ }^{x i}$ Chantal Mouffe, On The Political (London: Routledge, 2005), p.9. Mouffe has made this distinction elsewhere, such as 'Deliberative Democracy or Agonistic Pluralism?', Social Research , 66:3 (1999), p.754; and 'Democracy in a Multipolar World', Millennium, 37:3 (2009), p.550.

xii Chantal Mouffe, On The Political, p.10.

${ }^{x i i i}$ Chantal Mouffe, 'Democracy in a Multipolar World', p.550. See also Chantal Mouffe, 'Introduction', in The Challenge of Carl Schmitt, ed. Chantal Mouffe (London: Verso, 1999), p.3, where Mouffe states that 'To deny antagonisms in theory, however, does not make them disappear. They continue to manifest themselves, but with the proviso that now they can be perceived only as eruptions of the 'irrational' by those liberals who have denied their existence.'

xiv Chantal Mouffe, 'Democracy in a Multipolar World', p.550.

${ }^{\mathrm{xv}}$ Chantal Mouffe, 'Democracy in a Multipolar World', p. 550. Emphasis added.

${ }^{x v i}$ Carl Schmitt, The Concept of the Political (New Brunswick: Rutgers University Press, 1976).

${ }^{x v i i}$ Carl Schmitt, The Concept of the Political, p.27. 
xviii Chantal Mouffe, On the Political, p.11.

xix Anna Marie Smith, Laclau and Mouffe: The Radical Democratic Imaginary (London:

Routledge, 1998), p.129.

${ }^{x x}$ Carl Schmitt, The Concept of the Political, p.70.

${ }^{x x i}$ Chantal Mouffe, The Return of the Political, p.123; Chantal Mouffe, On the Political, p.11; and Chantal Mouffe, The Democratic Paradox, pp.48-51.

xxii Chantal Mouffe, The Democratic Paradox, p.49.

xxiii A similar critique has been levelled against Rawls' political liberalism by John Gray. See

John Gray, Enlightenment's Wake (London: Routledge, 2009), pp.114-115.

${ }^{x x i v}$ Anna Marie Smith, Laclau and Mouffe: The Radical Democratic Imaginary, p.130.

${ }^{x x v}$ Thomas Fossen, 'Agonistic Critiques of Liberalism: Perfection and Emancipation'.

${ }^{x x v i}$ For more on the perfectionist account of agonism, see David Owen, Nietzsche, Politics \& Modernity: A Critique of Liberal Reason (London: Sage, 1995); and Gerald M. Mara and

Suzanne L. Dovi, 'Mill, Nietzsche, and the Identity of Postmodern Liberalism', The Journal of Politics , 57:1 (1995), pp.1-23.

xxvii Thomas Fossen, 'Agonistic Critiques of Liberalism: Perfection and Emancipation', p.385. Emphasis added.

xxviii Chantal Mouffe, 'Deliberative Democracy or Agonistic Pluralism?', p.752.

xxix Ernesto Laclau and Chantal Mouffe, Hegemony and Socialist Strategy. Towards a Radical Democratic Politics (London: Verso, 1990).

${ }^{\mathrm{xxx}}$ See also Ernesto Laclau, 'The Impossibility of Society', in New Reflections on the

Revolution of Our Time, ed. Ernesto Laclau (London: Verso, 1990).

${ }^{x x x i}$ Chantal Mouffe, 'Deliberative Democracy or Agonistic Pluralism?', p.752.

xxxii Chantal Mouffe, 'Deliberative Democracy or Agonistic Pluralism?', p. 753.

xxxiii Chantal Mouffe, 'Deliberative Democracy or Agonistic Pluralism?', p. 753.

xxxiv This argument mirrors what Chambers takes to be the Critical Legal Studies account of power from within the judicial framework. As Chambers writes, a 'judicial understanding of power suggests that freedom and power are in an inverse relationship to one another - as one increases the other decreases. Put more precisely, within the juridical understanding power and freedom hold no relation to one another, since a relation to power creates precisely the conditions of unfreedom'. This understanding draws a distinction between the power that the individual may possess (individual agency) and the judicial model of power (judicial agency). Whilst it is possible for an individual to use their agency, judicial agency is seen as a negative force that acts against individual agency. Thus, it is only where there is no juridical power that there can be individual (negative) liberty. This is not a view that Chambers holds. Samuel Chambers, 'Giving Up (on) Rights? The Future of Rights and the Project of Radical Democracy’, American Journal of Political Science, 48:2 (2004), p.187.

${ }^{x x x v}$ Chantal Mouffe, Deliberative Democracy or Agonistic Pluralism, Political Science Series 72, Institute for Advanced Studies, Vienna (December 2000), p.14. Emphasis in the original. Whist this publication and the one referred to in $\mathrm{n} 11$ share not only a common name but also a great deal of substantive content, there are some minor differences between them.

xxxvi Chantal Mouffe, 'Deliberative Democracy or Agonistic Pluralism?', p.753.

xxxvii Chantal Mouffe, Deliberative Democracy or Agonistic Pluralism, p.14.

xxxviii Chantal Mouffe, 'Democracy in a Multipolar World', p.551.

xxxix Chantal Mouffe, 'Democracy in a Multipolar World', p.551.

${ }^{\mathrm{xl}}$ Chantal Mouffe, The Democratic Paradox, p.102.

xli Chantal Mouffe, 'Deliberative Democracy or Agonistic Pluralism?', p.755. 
xlii Chantal Mouffe, 'Deliberative Democracy or Agonistic Pluralism?,' p.755.

xliii Chantal Mouffe, Deliberative Democracy or Agonistic Pluralism, p.16; Chantal Mouffe, The Democratic Paradox, p.103; Chantal Mouffe, 'Introduction', p.4; and, Chantal Mouffe, On The Political, p.52.

${ }^{x l i v}$ Chantal Mouffe, Deliberative Democracy or Agonistic Pluralism, p.16.

${ }^{x l v}$ Katherine Walsh, 'The Democratic Potential of Civic Dialogue', in Deliberation,

Participation and Democracy: Can the People Govern?, ed. Shawn W. Rosenberg

(Basingstoke: Palgrave Macmillan, 2007), pp.45-63.

xlvi Chantal Mouffe, The Democratic Paradox, p.96.

xlvii Chantal Mouffe, 'Religion, Liberal Democracy, and Citizenship', in Political Theologies:

Public Religions in a Post-Secular World, eds. Hent de Vries and Lawrence E. Sullivan (New York: Fordham University Press, 2006), p.324.

xlviii Chantal Mouffe, The Democratic Paradox, p.96.

${ }^{x l i x}$ Chantal Mouffe, The Democratic Paradox, p.96. ${ }^{1}$ Chantal Mouffe, The Return of The

Political, p.6. ${ }^{\text {li }}$ Chantal Mouffe, On The Political, pp.24-25.

lii Fuat Gürsözlü, 'Debate: Agonism and Deliberation - Recognizing the Difference', The Journal of Political Philosophy, 17:3 (2009), pp.360-361.

liii Andrew Schaap, 'Agonism in Divided Societies', Philosophy \& Social Criticism, 32:2 (2006), pp.263-264. " ${ }^{\text {liv }}$ Chantal Mouffe, The Return of The Political, p.6.

${ }^{\text {lv }}$ Chantal Mouffe, The Democratic Paradox, pp.34-35. lvi Andrew Schaap, 'Agonism in Divided Societies'.

lvii Ilan Kapoor, 'Deliberative Democracy or Agonistic Pluralism? The Relevance of the Habermas-Mouffe Debate for Third World Politics', p.473.

lviii Ilan Kapoor, 'Deliberative Democracy or Agonistic Pluralism? The Relevance of the Habermas-Mouffe Debate for Third World Politics', p.473.

lix Ilan Kapoor, 'Deliberative Democracy or Agonistic Pluralism? The Relevance of the Habermas-Mouffe Debate for Third World Politics', p.473.

1x I examine in more detail the distinction between 'thin' and 'thick' forms of pluralism in Matthew Jones, 'Enlightenment Liberalism and the Challenge of Pluralism' (PhD thesis, Canterbury Christ Church University, 2012).

lxi Monique Deveaux, 'Agonism and pluralism', Philosophy \& Social Criticism , 25:4 (1999), p.5.

lxii Chantal Mouffe, 'Agonistic Democracy: Between Ethics and Politics', (lecture given at the Social and Political Thought series for the Department of Politics and International Relations, the University of Kent, November 3, 2011). Mouffe's statement was in response to a question asked by the author on this very issue.

Andrew Shorten, 'Cultural Diversity and Civic Education: Two Versions of the Fragmentation Objection', Educational Philosophy and Theory, 42:1 (2010), p.70. 